\title{
Sağlığın Kavramsallaştırılması ve İnsan Odaklı Sağlık Hizmetlerinde Kalite ve Akreditasyon Perspektifi
}

\author{
BAYRAM DEMIR* \\ bayramdemir2005@gmail.com
}

ORCID-ID: 0000-0003-2547-2664

Öz: Tarihsel süreç içerisinde sağllk hizmetlerinin odak nesnesi farklı toplum ve zamanlarda değişkenlik göstermiştir. Hastalı merkezli, hasta merkezli, toplum merkezli ve insan merkezli olmak üzere sağlı hizmetinin odağına yerleşen bu kavramlar sağlık hizmeti sisteminin tasarımında belirleyici olmuşlardır. Bunlara çatı oluşturan kavramsal yaklaşımların en önemlileri biyomedikal model ve biyopsikososyal modeldir. Hastalı ve sağlık durumuna ilişkin algılamaları belirleyen bu modeller insana ve insanın sağlı durumuna ilişkin farklı sayıltılara sahiptirler. 1980'li yıllara kadar biyomedikal modelin hâkim olduğu sağllk hizmetleri ve tıbbi pratikler alanı bulunmaktadır. 1948'de Dünya Sağlık Örgütü tarafından sağlık tanımına farklı bir bakış açısı getirilmiş olması biyopsikososyal modelin doğuşunu sağlamıştır. 1980’lerde başlayan sağlık reform dalgası 1990'lara gelindiğinde sağlık sistemlerine insan merkezli sağlik hizmetiyle uyumlu kalite ve akreditasyon çalışmaları entegre edilmiştir. Çalışmada biyopsikososyal modelin sağllk ve hastalık yaklaşımının insan merkezli sağlik uygulamaları ve kalite akreditasyon çalışmalarıyla ilişkisi tartışılmıştır.

Anahtar Kelimeler: İnsan odaklı sağhlk hizmeti, Biyomedikal model, Biyopsikososyal model, Kalite, Akreditasyon.

\section{Giriş}

İnsanlığın ortaklaşa yaşama geçtiği dönemlerden bu yana sağlık hizmetlerinin sunumu değişim ve dönüşüm geçirmiştir. Tıbbın günümüzde ulaştığ ${ }_{1}$ aşamalar ilkel sağlık hizmeti sunumundan, modern batı tıbbının hâkim olduğu günümüze kadar değişim ve de dönüşümü bizlere göstermektedir. İlkel sağlık hizmeti sunumunda insan aklının açıklayabildiği ve eldeki araç ve gereçlerle çözüm bulduğu sorunlar ve hastalıklar halk tıbbı pratiği içinde değerlendirilirken, açıklayamadığı ve çözemediği sağlık sorunlarının çözümü doğaüstücü yaklaşımların geçerli olduğu pratiklere

\footnotetext{
* Dr. Araştırmacı, Sağlık Bakanlığı.
} 
bırakılmıştır. ${ }^{1}$ Günümüzde ise, modern batı tıbbının hâkim yaklaşım olduğu yadsınamaz bir gerçektir. Öte yandan halen halk tıbbının ve diğer doğaüstücü yaklaşımın izlerine de rastlanmaktadır. Her yaklaşım bir paradigma olarak değerlendirilecek olursa aynı dönemde birden fazla paradigmanın varlık gösteriyor olduğu ifade edilebilir.

Thomas Kuhn'un belirttiği paradigma dönüşümleri sadece bilimsel açılama iddiasındaki teorilerin etkilendiği bir husus değildir. ${ }^{2}$ Ortaya koyduğu çerçeve sağllk hizmet sunumunun gerisinde yatan yaklaşımları da açıklamaktadır. Sosyologlara göre paradigma dönüşümü sağlık hizmet sunumunun kavramsallaştırılmasında da yaşanmaktadır. Castelle göre hakim paradigma olan biyomedikal modelin "hasta" kavramının yerini "birey veya kişi” kavramı almıştır. ${ }^{3}$ Sağlık hizmet sunucuları ise sağlık hizmet sunumundaki paradigma dönüşümünün hastalık-hasta ve kişi odaklı sağlık hizmeti şeklinde yaşandığını belirtmektedir. İkinci dünya savaşına kadar tıp, akut hastalıkların eradikasyonuna odaklanmıştır. 1946 yılında Dünya Sağlık Örgütü sağlıklı olmanın sadece hastalığın olmadığı bir hal olmadığı şeklinde bir sağlık tanımı formüle ederek kavramsal düzeyde tıbbın sağlığa bakış açısını değiştirmeye başlamıştır. Aile hekimliği, psikiyatri gibi tıp branşlarının yaygınlık kazanmasıyla birlikte tıbbın indirgemeci sağlık yaklaşımı değişmiş, psikososyal faktörlerin etkisinin artmasıyla beraber "hasta odaklı yaklaşım" ortaya çıkmıştır. Bu yaklaşım günümüzde birçok tıp disiplininin ana eksenini de biçimlendirmektedir. 2000'li yıllara gelindiğinde ise sağlık hizmet sunumunda ana tema "toplum odaklı sağlık hizmeti” şekline dönüşmüştür. ${ }^{4}$

Dünya Sağlık Örgütü’nün sağlık tanımı, hastalı̆ı̆ı yokluğu durumuna yaparak farklı bir model önermekte ve kişinin biyopsikososyal çevresini dikkate alan sağlık kavramlaştırması yaklaşımı ise farklı bir sağlı durumu değerlendirmesini ortaya koymaktadır. Hizmetlerin odak noktasını hangi kavramın oluşturduğu sağlık sisteminin tasarımını etkilemektedir. Hasta odaklı sağlık hizmeti, insan odaklı sağlık hizmeti veya toplum odaklı sağlık hizmeti tamlamalarının her biri ayrı ideolojik, politik ve teknik angajmanlarla desteklenen sağlık hizmetlerini ortaya çıarmaktadır.

Bununla birlikte ülkelerin sağlık sistemleri temel olarak iki ana başlıkta ele alınabilir. Birincisi toplumun sağlık ve hastalık hakkındaki inançları, yaşam ve ölüme dair algıları, bunlara atfettiği anlam ve hastalık durumunda tutum ve davranışlarını içeren sosyokültürel yaklaşımları; ikincisi ise sağlık hizmeti sunumunu oluşturan fiziksel yapıları, teknolojik alt yapısı, sağlık insan gücü, hizmet sunum süreçleri ve hizmetin finansmanını içeren örgütlenmesi olmaktadır. ${ }^{5}$ Öte yandan sağlık dâhil birçok sektörde insanlara ve dolayısıyla topluma sunulan hizmetlerin nitelik olarak güvenli ve kullanıcı dostu olarak sürdürülmesini sağlayan felsefi ve teknik yöntem

1 Richard K. Thomas, Society and Health -Sociology for Health Professionals, New York: Kluwer Academic Publishers, 2003, s.78-80.

2 Thomas Kuhn, The Structure of Scientific Revolutions. London: The University of Chicago Press, 1996.

3 Sarah Netletton, The Sociology of Health and Ilness, Cambridge: Polity Press, 1995, s. 12, 251-252.

4 Jan De Maeseneer, vd., "From "Patient" to "Person" to "People": The Need for İntegrated, People-Centered Healthcare", The International Journal of Person Centered Medicine, 2/3 (2012), s. 601-614.

5 Thomas, Society and Health, s.77. 
olarak kalite ve akreditasyon çalışmaları, sağlık hizmetlerinde insan odaklı sağlık hizmet sunumu için organizasyonlara önemli bir seçenek sunmaktadır. Çünkü standartların altındaki sağlık hizmetinin hem insani hem de ciddi finansal sonuçları olabilmektedir. ${ }^{6}$ Bununla birlikte, sağlık hizmetlerinde kalite ve akreditasyon faaliyetleri sağlık hizmetleri sunumunda uzun yıllardır kendisine yer bulan, sağlık ve hastalığa dair kavramsal dönüşümleri içinde barındıran düzenleyici faaliyetler bütünü olarak işlevsel bir mahiyete sahiptir. Bu çalışmada "insan odaklı sağlık hizmeti" kavramsallaştırması içinde sağlık hizmetlerinin iyileştirilmesinde kalite yönetimi ve akreditasyon faaliyetlerinin önemi tartışılmaya çalışlacaktır. Bu çerçevede öncelikle sağlık hizmetlerinin odağındaki kavramlar ve sağlığın kavramlaştırılması modellerinin içeriğine yer verilecektir.

\section{Sağlık Hizmetlerinde Odak Nesnesinin Değişimi}

Sağlık olgusu, insanoğlunun gündelik hayatında merkezi bir role sahiptir. Sağlı̆̆ın önemi ise, genellikle kaybedildiği anlarda anlaşılmaya başlanır. Sağlık durumunun kötü olması insanın sadece bedeni üzerinde değil, aynı zamanda yaşantısı, kendi hakkındaki düşünceleri ve başkalarıyla olan etkileşimleri açısından da önemli sonuçlar doğurur. Daha da ötesinde, insanların kimlik algısı, yaşam tarzı ve sosyal ilişkileri de sağlıklı olma haliyle şekillenmektedir. Bu nedenle, kişinin sağlık durumunun kötüleşmesi halinde hizmet aldığı sağlık kurumlarının ve etkileşimde bulundukları sağlık profesyonellerinin hasta-hastalık haline yaklaşımları, en az sağlıklı olma haline yaklaşımları kadar merkezi bir role sahiptir.

Bununla birlikte, sağlık hizmetlerinin sunumunu tanımlamada sağllk profesyonellerinin bakış açısını da içerecek şekilde temel olarak birkaç yaklaşımın olduğu ifade edilebilir. Bunlar tedavi edici sağlık kurumları için, "hastalık merkezli", "hasta merkezli sağllk hizmeti", "kanıt temelli sağlık hizmeti" ve insan merkezli sağllk hizmeti; birinci basamak, temel sağllk hizmetleri ve koruyucu sağllk hizmetleri için ise "hasta merkezli" ve "toplum merkezli sağllk hizmeti" şeklinde bir değişim skalası söz konusudur. ${ }^{7}$ Hizmet sunumunu merkez alan bu ayırım giderek kamu sağllk politikalarının seyrini de belirlemektedir. Yaklaşımlar zaman içerisinde değişerek ve genel itibarıyla yerini bir diğer bakış açısına bırakmakla birlikte aynı habitat içinde var olmaya devam etmeleri de söz konusu olabilmektedir. Buna karşlık sağlık hizmet sunumunun odak nesnesinde dört temel aşamaya yer verebiliriz.

\section{Hastalık Merkezli Sağlık Yaklaşımı}

Genel itibarıyla hastaların tıbbi durumlarına ilişkin raporları hastalık süreçlerinin ifadesi olarak değerìendirilimekte ve k̉inik yöntem olarak da hastalıkiarı sayısal veriler üzerinden tanımlamaya odaklanmaktadır. Bir yönüyle kanıta dayalı tedavi olarak da değerlendirilebilir. Bu klinik yöntemin, basit, açık, doğrulanabilir olma gibi güçlü yönleri bulunmasının yanında hastalık biyolojik olarak da tanımlanabilir.

6 Reece Hinchcliff vd., "Stakeholder Perspectives on İmplementing Accreditation Programs: A Qualitative Study of Enabling Factors", BMC Health Services Research, 13/437 (2013), s.2-9.

7 Jan De Maeseneer vd., "From "Patient" to "Person" to "People": The Need for İntegrated, People-Centered Healthcare", s.603-604. 
Klinisyenlerin neden-sonuç ilişkilerini ve hastalığın süreçlerini tanımlamasına izin verir. Bununla birlikte, hastalığı bedenin ölçülebilir biyolojik değişkenlerinin normundan sapmalar olarak görmesi ve hastanın bakış açısını dikkate almamasının yanı sıra hastalık halinin sorunlarını aşırı basitleştirilmesi nedeniyle eleştirilmiştir. ${ }^{8}$ Temelinde tıp teknolojisinin ilerlemesi ve tıptaki uzmanlaşma bulunmakla birlikte, bireyleri "vaka" olarak gören vetedavi/bakım sürecinde bireyin sosyokültürel ve insancıl yönlerinin göz ardı edilmesi yatmaktadır. Bir paradoks olarak da sağlık kurumlarına güvenin azalması ve alternatif tıp felsefelerinin ve uygulamalarının yükselişini etkilediği ifade edilmektedir. ${ }^{9}$ Bununla birlikte, tıp eğitimi biyomedikal yöntemi temel almaktadır. Hekimler "hastalık merkezli" yaklaşıma göre yetişmektedirler. Bu yaklaşıma göre hekimin görevi, hastalığın tanımlanması, açıklanması, nedenlerinin ortaya konması ve sonrasında bunların önlenmesi ve tedavi edilmesi şeklindedir. Hasta ile iletişimin içeriği de hastaya tanı konulmasına yönelik olmaktadır. ${ }^{10}$ Paternalistik karaktere sahip bu süreçlerde hastaya pasif bir rol biçilmiş olmaktadır.

\section{Hasta Merkezli Sağlık Yaklaşımı}

20. yüzyılda hasta memnuniyetini artırma ve tedavi sonuçlarını iyileştirme vaadi ile sağlık sistemlerinin merkezinde yer etmiş olan "hasta odaklı" yaklaşımın tanımı, ilk defa Balint tarafından, "hastayı benzersiz bir varlık olarak anlamak" şeklinde yapılmıştır. ${ }^{11}$ April Reynolds'a göre, hasta merkezli bakım, hastaya ve bireyin özel sağlık bakımı ihtiyaçlarına odaklanır. Hasta merkezli sağlık hizmetlerinin amacı hastaların kendi tedavi süreci ve bakımlarında aktif katılımcılar olmalarını sağlamaktır. ${ }^{12}$ Hasta merkezli sağlık hizmeti; hastanın istek, ihtiyaç ve önceliklerinin dikkate alındığı hekim, hasta ve hasta yakını arasındaki işbirliğini vurguladığı gibi hastanın tedavi sürecine katılması sağlanarak, doğru karar almasına yönelik ihtiyaç duyduğu tüm bilgilerin paylaşılmasıdır. ${ }^{13}$ Bu yaklaşım, temelinde klinik araştırmaları içeren, hasta bireyi tedavi etmek ve bireyin sadece sağlık bakımına odaklanmak olarak anlaşılmaktadır.

\section{Toplum Merkezli Sağlık Yaklaşımı}

Toplum merkezli sağlık hizmeti ise daha farklı bir bakış açısı sunmaktadır. Dünya Sağlık Örgütü'ne göre, toplum odaklı sağlık hizmeti hastalık durumundan çok topluma ve çevresine odaklanmış sağlık hizmeti anlamına gelmektedir. Toplum

8 Lidia Borghi vd., "Promoting Patient Engagement and Participation for Effective Healthcare Reform", The Patient-Centered Medicine as the Theoretical Framework for Patient Engagement, ed., Guendalina Graffigna, USA: IGI Global, 2016, s.27.

9 Alexander R. Green, Juan Emilio Carrillo ve Joseph R. Betancourt, "Why the Disease-Based Model of Medicine Fails our Patients", Western Journal of Medicine, 176/2 (2002), s. 141-143.

10 Gülay Şahin ve Füsun A. Artıran İğde, "Hasta Merkezli Bakım-Ortak Karar Alma Süreci ve Kalite", Turkiye Klinikleri Journal of Family Medicine-Special Topics, 5/3 (2014), s. 38-42.

11 Gemmae M. Fix vd., "Patient-Centred Care is a Way of Doing Things: How Healthcare Employees Conceptualize Patient-Centred Care", Health Expectations, 21/1 (2018) :300-307.

12 April Reynolds, "Patient-Centered Care", Radiol Technol, 81 (2009), s.133-147.

13Banu Kumbasar, "Hasta Odaklı Sağlık Hizmetlerinde İletişim”, Sağlık Bilimleri ve Meslekleri Dergisi, 3/1 (2016), s.85-90. 
merkezli hizmet, yalnızca hasta birey yerine insanlara odaklanmış ve sağlık hizmeti buna göre örgütlenmiştir. ${ }^{14}$ Hastalıklardan korunma ve hastalık yönetimi önemli görülmekle birlikte toplumun ihtiyaç ve beklentilerini karşılama noktasında yeterli olarak değerlendirilmez. Merkezinde, ailesi, toplumu ve içinde bulunduğu kültürel bağlamı dikkate alınan bağlamında kişi bulunmaktadır. Yaklaşım ayrıca, toplumdaki insanların sağlık politikası ve sağlık hizmetlerinin şekillendirilmesindeki rolüne dikkat çekmektedir.

\section{İnsan Merkezli Sağlık Yaklaşımı}

Sağlık hizmetlerinin söylem düzeyindeki odak evriminin bir diğer noktasının “insan merkezli sağlık hizmeti” olduğu belirtilebilir. İnsan merkezli bakım konusunda büyük bir alan yazını olmasına ve bu terimin sağlık politikası ve araştırmasına sıklıkla dâhil edilmesine rağmen, üzerinde anlaşmaya varılmış standart bir tanımı bulunmamaktadır. ${ }^{15}$ Miles ve Mezzich insan odaklı sağlık hizmetini, tıbbın imkânlarını uygun bir şekilde hastalara sunan ve hümanistik çerçevede kişiyi bir bütün olarak kabul edip, fiziksel ihtiyaçlarına ilave olarak korkularını, duygularını, geçmişini, kültürel bağlamını, ruhsal ihtiyaçlarını da dikkate alan felsefe ve metot olarak tanımlamaktadır. ${ }^{16}$ Morton ve Sellars'a göre bu felsefi yaklaşımın hizmet sunumundaki karşılığını ise şu ilkelerde görebiliriz: (1) Tedavi ve bakım kişiye onur, merhamet ve saygı ile verilir; (2) tedavi ve bakım iyi koordine edilmiştir; (3) Tedavi ve bakım, kişinin klinik, sosyal, duygusal ve pratik ihtiyaçlar dikkate alınarak kişiselleştirilir; ve (4) insanların kendi tedavilerinde aktif rol almalarını sağlar. Hastalığa odaklanmaktan ziyade kişiye, ailesine ve sosyal çevresine odaklanmayı tanımlar; hizmetten yararlanan kişiyi, pasif alıcı olarak değil sağlık profesyonelleriyle eşit bir ilişkiyi destekler. ${ }^{17}$ İnsan odaklı sağlık hizmeti kişilerin kendi sağlık ve iyilik durumunu kontrol etmesini desteklediği gibi kişilerin bu yöndeki gayretlerini de birçok anlamda desteklemektedir. ${ }^{18}$ Ayrıca DSÖ’ye göre insan merkezli sağlık hizmetlerine ilişkin genel vizyon, bireylerin, ailelerin ve toplulukların ihtiyaçlarına insani ve bütüncül yollarla cevap veren güvenilir bir sistem tasarımıdır. Böylelikle, sağlık sistemi, paydaşların ihtiyaçları etrafında tasarlanır. Bireylerin, ailelerin ve toplulukların sağlı hizmetlerinin kalitesinde ve ihtiyaçlara yanıt verebilirliğinde iyileşme sağlamak için kamu otoritesi, özel ve kar amacı gütmeyen sağlık kuruluşlarının işbirliğini sağlar. ${ }^{19}$

Her ne kadar ağırlık merkezi farklı sağlık hizmeti sunum anlayışları söz konusu ise de bunların mutlak bir şekilde birbirinden ayrıştırılabilmesi mümkün olduğu

14 World Health Organization, People Centered Healthcare, Geneva, 2008.

15 The American Geriatrics Society, "Person-Centered Care: A Definition and Essential Elements", Journal of American Geriatrics Society, 64 (2016), s.15-18.

16 Andrew Miles ve Juan E. Mezzich, “The Care of the Patient and the Soul of the Clinic: Personcentered Medicine as an Emergent Model of Modern Clinical Practice", The International Journal of Person Centered Medicine, 1/2 (2011), s. 207-222.

17 Rachael L. Morton ve Marcus Sellars, "From Patient-Centered to Person-Centered Care for Kidney Diseases", Clinical Journal of the American Society of Nephrology, 14 (2019), s. 623-625.

18 Yuri Quintana, "People Centered Healthcare Systems: Opportunities and Challenges", British Medical Journal Satellites, 18 (2011), s. 17-24.

19 World Health Organization, People Centered Healthcare. 
düşünülmemektedir. Zira hasta merkezli ve insan merkezli yaklaşım birçok açıdan benzerlikler göstermektedir. Dolayısıyla bu kavramlar bunlar birer ideal tip olarak değerlendirilebilir. Çünkü sağlık hizmetlerinin uygulama karakteristikleri sistemin işleyişindeki merkezi yaklaşımın anlaşılmasına imkân vermektedir. Böyle bir kestirimde bulunmayı kolaylaştıran bir diğer enstrüman ise sağlığı ve sağllk hizmetlerinin sunum pratiklerini tanımlamada kullanılan kavramsal modellerdir.

\section{Sağlık Kavramsallaştırması Modelleri}

Sağlık veya hastalık doğrudan tıbbi faaliyetleri çağrıştırıyor da olsa aynı zamanda sosyo- kültürel bir olgudur. Bu nedenle sosyolojik olarak da ele alınması gereken bir olgudur. Ayrıca sağlık, ilk bakışta üzerinde kolaylıkla anlaşılabilecek ve ortak bir tanım yapılabilecek bir alan gibi görünmesine karşın oldukça değişken bir içeriğe sahiptir. Üzerinde ortak bir yaklaşım geliştirilememesinin de haklı sebepleri bulunmaktadır. Çünkü sağlık sadece tıbbi değil, sosyal, psikolojik, ruhsal, çevresel ve ekonomik olmak üzere birçok bileşene sahiptir. Dolayısıyla aşağıda yer verilecek modeller de genel itibarıyla sağ lık durumunu tanımlama üzerinden ayrışmaktadırlar. $\mathrm{Bu}$ algılama biçimleri sadece klinik uygulamada yaşanan bir dil sorunu açısından önem arz etmez. Aynı zamanda nelerin sağlık sorunu olarak değerlendirileceği, sağlık sorunlarından hangisinin öncelikli olarak ele alınacağı, sağlık hizmetinin nasıl sunulması gerektiği ve sağlık hizmet tasarımı konusunda da sağlık politikası ve uygulamalarını mikro ve makro ölçekte farklılaştırabilmektedir. ${ }^{20}$

Hastalık, hasta, toplum ve insan merkezli sağlık hizmeti çatısı altındaki bütün sağlık hizmet sunum pratiklerinin sağlığa ilişkin genel algılamalardan etkilendiği düşünüldüğg̈nde bu algılamaları şekillendiren genel bir çerçeve, yani bu algılamaların karşılık geldiği kavramsal modeller bulunduğu anlaşılmaktadır. Diğer bütün kavramlar gibi sağlık ve hastalık kavramları da başta öznellik ve nesnellik olmak üzere birçok boyutu içermektedir. ${ }^{21}$ Geçerli olan hâkim kavramlaştırma sağllk ve hastalık durumuna dair temel açıklamaları da belirlemektedir. Bu çerçevede, kavramsal modeller farklı şekillerde adlandırılabilmektedir.

20 Tuğrul Erbaydar, “Sağlık; Kimin için?”, Toplumbilim Dergisi, 13 (2001), s. 49-58.

21 Aytül Kasapoğlu, "Güncel Sosyal Sorunlar ve Sağlık”, Toplumbilim Dergisi, 13 (2001), s. 23-37. 
Tablo1: Sağhlğı Tanımlama Modelleri

\begin{tabular}{|l|l|}
\hline \multicolumn{1}{|c|}{ Model } & \multicolumn{1}{c|}{ Tanım } \\
\hline $\begin{array}{l}\text { Tibbi/Biyomedikal } \\
\text { Model }\end{array}$ & Hastalık veya sakatlık halinin yokluğu \\
\hline $\begin{array}{l}\text { Dünya Sağlık Örgütü / } \\
\text { Biyopsikososyal Model }\end{array}$ & $\begin{array}{l}\text { Yalnızca hastalık ve sakatlık halinin olmaması değil fiziksel, } \\
\text { ruhsal ve sosyal olarak tam bir iyilik hali }\end{array}$ \\
\hline İyilik Modeli & $\begin{array}{l}\text { Sağllğın desteklenmesi ve verimli yaratıcı yaşam için optimum } \\
\text { kişisel uygunluk ve de zihin, beden ve ruhun bütünleşmesi } \\
\text { dolu, }\end{array}$ \\
\hline Çevresel Model & $\begin{array}{l}\text { Fiziksel ve sosyal çevreye uyum - aşırı acı, rahatsızlık veya } \\
\text { sakatlıktan uzak bir denge }\end{array}$ \\
\hline $\begin{array}{l}\text { Sosyal ya da İşlevsel } \\
\text { Model }\end{array}$ & Bireylerin sosyal olarak işlevsel olma yeteneği \\
\hline Psikolojik Model & $\begin{array}{l}\text { Sağlıklı olma hali kişinin kendi durumu hakkındaki öznel } \\
\text { değerlendirmesidir. }\end{array}$ \\
\hline
\end{tabular}

Kaynak: James S. Larson, “The Conceptualization of Health”, Medical Care Research Review, 56/2 (1999), s.125; Encyclopedia of Sociology, Donald E. Stull, 2000, "Health and the Life Course" maddesinden uyarlanmıştır.

Tablo 1'de yer verilen modellerden yaygın olarak kendine yer bulanların hiç kuşkusuz Biyomedikal model ve Dünya Sağlık Örgütü modeli olduğu ifade edilebilir. Geleneksel olarak sağlık, hastalık durumun yokluğu ile eşdeğer kabul edilir. Temel olarak bedeninde patolojik bir bozukluğun olmadığı hallerde kişiyi sağlıklı kabul etmek söz konusu iken patojenler nedeniyle bedensel zayıflığın oluşması hallerinde ise kişiyi hasta olarak nitelendirmek mümkün olmaktadır. Kuşkusuz bu türden dar bir bakış açısı iyilik halini anlaşılmasını zorlaştıracak ve tedaviye yönelik çabaları boşa çıkaracağı gibi koruyucu önlemleri de baskılayabilecektir. Dolayısıyla hastalık ve sağlığa yönelik temel yaklaşımların anlaşılması ayrıca önem kazanmaktadır. Biyomedikal ve biyopsikososyal modelin anlaşılması bu yönüyle de dikkate alınmalıdır.

\section{Biyomedikal Model}

Modelin ayırıcı yönü, sağlığın tanımı ile belirgin bir yaklaşım göstermektedir. Model, sadece bireyin fizyolojik durumuna ve hastalık belirtilerinin varlığına veya yokluğuna odaklanır. Buna göre, sağlık durumu, kişinin bedeninde hastalı̆̆ın olmaması; hastalık ise kişinin bedenindeki fizyolojik bir problem olarak algılanır. Burada asıl olan olumlu bir durumun tespiti yapılmayıp sadece olumsuz bir durumun yokluğunun tespit edilmesidir. Dolayısıyla kişi hasta değilse iyi addedilebilir. Wolinsky’e göre biyomedikal modelin sağlık ve hastalık durumuna dair kavrayışı güçleştiren dört temel sayiltısı bulunmaktadır:22

22 Gregory L. Weiss ve Lynne E. Lonnquist, The Sociology of Health, Healing and Illness, New York: Routledge, 2016, s.169. 
- Hastalığın varlığı, teşhisi ve tedavisi tamamen nesnel olgulardır. Kişide ortaya çıkan semptomlar ve elde edilen bulgular kesin tanının hatasız olarak yapılabileceği doğru ve objektif bilgi verir.

- Sadece sağlık profesyonelleri (hekimler) sağlığı ve hastalıkları tanılayabilir.

- Sağlık ve hastalık sadece fizyolojik problem olarak tanımlanmalıdır.

- Sağlık sadece hastalığın olmaması olarak tanımlanır.

Engel'e göre ise, tıbbi yaklaşımlar içinde önemli bir yer tutan biyomedikal model, hastalık halinin ölçülebilir bedensel normlardan tamamıyla bir sapma olduğu sayıltısına sahiptir. Hastalığın sosyal, psikolojik ve de davranışsal yönüne alan bırakmaz. Hastalık, dışarıdan nüfuz ederek bireyin bedeninin fizyolojik yapısını ve ruhsal dengesini bozan bir etken olarak görülür ve bedensel süreçlerdeki sapmaların da hastalık halinin bir sonucu olduğunu ifade eder. ${ }^{23}$

Modelde hastalıkların dış veya iç kaynaklı yaralanmalardan ortaya çıktı̆̆ı vurgulanır. Hastalı̆̆ın diş nedenleri fiziksel, kimyasal ve mikrobiyolojik; iç nedenleri ise vasküler, immünolojik ve metabolik olarak üç büyük kategoriye ayrılır. Vücudun organlarını esas alan tıbbi uygulama, hücre, doku ve organ işleyişi hakkındaki bilgiyi artırabileceği gibi bazı hastalıkların gelişme ve tedavi mekanizmalarını ortaya çıkarabilecektir. Ancak, hastalıkların daha geniş psikososyal yönlerini hesaba katmadığ iç̧in kronik hastalıkların yayılımını azaltmak için gereken önleyici çabaları yönlendirmede çok az şey sunmaktadır. ${ }^{24}$ Öte yandan, bu yaklaşımın indirgemeci tutumu nedeniyle modern tıbbi uygulamayı insani çerçeveden uzaklaştırıyor oluşu sağlık hizmetlerine ihtiyaç duyan kişilerin memnuniyetsizliğine yol açmaktadır. Modern biyomedikal tıbbi yaklaşımdan ortaya çıkan memnuniyetsizliğin doğrudan bir sonucu olarak tamamlayıcı ve alternatif yaklaşımlar geliştirilmekte ve rağbet görmektedir

Edwards’a göre, modern tıp öncelikle aile hekimleri, hastaneler, bakım evleri ve benzeri gibi sağlık kuruluşları aracılı̆̆ıyla halka sunulmaktadır. Zaman içinde piyasa ilkeleri de sağlık hizmetinin bir parçası olmuştur (örneğin, özel sağlık sektörü, tedavilerin ticarileştirilmesiyle ilaçlardan büyük karlar elde edilmesi). Biyomedikal modelde modern tıp açısından bilimsel uzmanlık değerli olup ve sıradan insanların görüşü önemli addedilmez. Sağlık profesyonelleri açısından asıl olan uzman bilgisiyle hastalığı tanımlamak, tedavi etmek ve önlemek için bilinen usullere bağlı kalmaktır. $\mathrm{Bu}$ nedenle modern tıp, bürokrasi, pazar ve tıbbi uzmanlığın gücü tarafından yönetilen bir kurumdur. ${ }^{25}$ Biyomedikal modele yönelik bu eleştiri, günümüzde neredeyse kutsal bir kavram olarak değerlendirilen "hasta katılımı"na yer vermediği ve dolayısıyla sağlık hizmetinden yararlanan kişilerin aktif bir paydaş olarak sistemde yer almasını engelliyor olduğudur.

23 George L. Engel, "The Need for a New Medical Model: A Challenge for Biomedicine”, Science, 196 (1977), s.129- 136.

24 Mladen Havelka, Jasminka Despot Lucanin ve Damir Lucanin, "Biopsychosocial Model - The Integrated Approach to Health and Disease", Collegium Antropologium, 33/1 (2009), s. 303-310.

25 Gemma Edwards. "Jürgen Habermas Politics and Morality in Health and Medicine",

Contemporary Theorists for Medical Sociology, ed., Graham Scambler, New York Routledge, 2012, s.38. 
Anjum'a göre, biyomedikal modelin havzası içinde yer alan hastalık ve hasta merkezli anlayışların yerini bıraktı̆̆ı" insan odaklı sağlık hizmeti”, tıptaki değişimin tıbbi pratik ve değerlerin ötesinde olduğunu temsil etmektedir. Ayrıca biyomedikal modelin tek nedenselci, indirgemeci ve mekanik yaklaşımından uzaklaşarak modelin ontolojik çerçevesini etkilediği gibi bireyi içeren bir sağlık hizmetini teşvik ederek kökeni 18. yüzyıla uzanan biyomedikal yaklaşımı eleştirmiş olduğunu da belirtmektedir. ${ }^{26}$

Sağlık statüsünü belirleyen birçok parametre bulunmaktadır. Bunlardan bazıları; üreme sağlı̆̆ı, aşılama, mortalite, morbidite, fertilite gibi parametrelerdir. Ama bu parametreler sistemin bütününü görmeyi ve değerlendirebilmeyi sağlamadığ ve diğer unsurları ihmal ettiği için sağlık durumuna dair saptamalarda 1skalaması yüksek olan yaklaşımlardır. Dolayısıyla indirgemeciliğin ötesinde bütüncül bir bakış açısına ihtiyaç bulunmaktadır.

\section{Biyopsikososyal Model}

Biyomedikal modelin indirgemeci ve hasta katılımını öngörmeyen yaklaşımı Dünya Sağlık Örgütünün sağlık tanımıyla birlikte tartışılmaya başlanmıştır. 1960’lardan itibaren kronik hastaların deneyimlerinin klinik düzeyde ifadesinin biyomedikal bakış açısına nüfuz etmesi toplumun ve tıbbın karşılıklı etkileşiminin bir ürünü olarak ortaya çıkmıştır. Yine 60’lı yılların kültürel ve politik değişimleri ışı̆̆ında hastalar ve sağlık çalışanları da hastalık deneyimlerinin nesneleştirilmesinden şikâyetçi olmuşlardı. Çünkü klinik prosedürlerin ve tıbbi uygulamaların nesneleri olarak görülen hastalar kendilerini sadece tedavilerinin seyri hakkındaki kararlardan değil, aynı zamanda kendi bedenlerinden ve yaşamlarından da yabancılaşmış görüyorlardı. Bunun temelinde ise, hasta/kişi deneyimini tıbbi bilgiden ayıran bir tür biyomedikal paternalizm olduğu görülmüştür. ${ }^{27}$

Organlarda meydana gelen bir işlev bozukluğunun ortadan kaldırılması durumunda bile bireyin sağlık durumunun stabil hale getirilemeyeceği, yani bütüncül bir bakış açısı ile bireyin psikososyal durumunu dikkate almayan bir yaklaşımın ihtiyaca cevap veremeyeceği düşüncesi Dünya Sağlık Örgütü’nün medikal alan ve medikal olmayan alan bir araya getiren sağlık tanımlamasıyla somutlaşmıştır. ${ }^{28}$

Buna göre sağlık, "sadece hastalık veya sakatlığın olmayışı değil, fiziksel, ruhsal ve sosyal açıdan tam bir iyilik halidir” şeklinde tanımlanmıştır. Dünya Sağlık Örgütü modeli olarak bilinen bu yaklaşım aynı zamanda "biyopsikososyal model" olarak da adlandırılmaktadır. Biyopsikososyal model, tıbbın pür bilimsel özellikleri üzerine inşa edilen biyomedikal modele göre insan davranışına ve hastalığa daha geniş ve entegre bir yaklaşım sunar. ${ }^{29}$ "Biyopsikososyal" kavramı ilk olarak 1954 yılında Grinker tarafından kullanılmış olup daha sonra bir dönüm noktası olarak George

26Rani Lill Anjum vd., "Integrating Philosophical Perspectives İnto Personcentered Healthcare”, European Journal for Person Centered Healthcare, 3/4 (2015), s. 427-430.

27Carl May, "Mundane Medicine, Therapeutic Relationships and the Clinical Encounter: Current and Future Agendas for Sociology", Handbook of the Sociology of Health, Illness and Healing, ed., Bernice A. Pescosolido vd., London: Springer, 2011, s.313.

28 Erbaydar, “Sağlık; Kimin için?”, s.50.

29 Ahmad Dogar Imtiaz, "Biopsychosocial Model”, Annals of Punjab Medical College, 1/1(2007), s.11-13. 
Engel tarafından model olarak zikredilmeye başlanmıştır. Engel genel sistem teorisini temel alan yaklaşımının tıbbi alana uygulandığında biyolojik, psikolojik ve sosyal süreçlerin her birinin sağlık hizmetinin sunumunun her aşamasında dikkate alınması gerektiğini vurgulamıştır. Çünkü bu öğeleri fiziksel sağlık ve hastalık durumunun ayrılmaz ve etkileşimli parçası olarak değerlendirmektedir. Biyopsikososyal model hastalığı, organizma düzeyinde ve kişiler arası ve çevresel seviyelerde etkileşime giren mekanizmaların sonucu olarak görür. ${ }^{30}$ Biyopsikososyal model hastalığı organizma düzeyinde, kişiler arası ve çevresel seviyelerde etkileşime giren mekanizmalardan kaynaklandığ1 sayıltısına sahiptir. Buna göre, her türlü hastalığa dair inceleme, sistemin temel bileşenleri olarak bireyi, vücudu ve çevresindeki ortamı içerecek şekilde yapılmalıdır. Zira sağlık ve hastalık sosyal yapı içinde oluşur ve onun tarafından şekillendirilir. Bu nedenle sağlık ve hastalık toplumsal ve de çevresel etkenlerden bağımsız değildir. Ona anlamını veren de toplumun onu algılayış biçimidir. $\mathrm{Bu}$ yüzden, biyomedikal modelin medikalizasyon kavramının aksine neyin hastalık olup olmadığ tarihselliği içinde her toplumda değişkenlik göstermektedir. ${ }^{31}$

Her iki yaklaşım kendi içinde farklı bir perspektif taşımaktadır. Buna karşılık biyopsikososyal model daha geniş bir çerçeveyi kapsamaktadır.

\section{Biyomedikal ve Biyopsikososyal Modelin Karşılaştırılması}

Her iki modelin hastalık ve sağlık hakkındaki yaklaşımları birbirinden farklılık arz etmektedir. Sağlık çerçevesinde insana ve insan doğasına ilişkin önemli ayırım bulunmaktadır. Her iki yaklaşım farklı sayıltılara sahiptir. Bu çerçevede, farkları gösteren bir tabloya yer vermek daha aydınlatıcı olacaktır.

30 Ana Sabela A 'lvarez, Marco Pagani ve Paolo Meucci, “The Clinical Application of The Biopsychosocial Model in Mental Health: A Research Critique”, American Journal of Physical Medicine \& Rehabilitation, 91 (2012), s.173180.

31 Ömer Aytaç ve Muzaffer Çağlar Kurtdaş, “Sağlık - Hastalığın Toplumsal Kökenleri ve Sağlık Sosyolojisi”, Firat Üniversitesi Sosyal Bilimler Dergisi, 25/1 (2015), s. 231-250. 
Tablo 2: Biyomedikal ve Biyopsikososyal Modelin Karşılaştırılması

\begin{tabular}{|c|c|c|}
\hline Odak noktası & Biyomedikal Model & Biyopsikososyal Model \\
\hline $\begin{array}{l}\text { Hastalığın sebebi } \\
\text { nedir? }\end{array}$ & Biyolojik faktörler & $\begin{array}{l}\text { Biyolojik, psikolojik ve sosyal } \\
\text { faktörler }\end{array}$ \\
\hline $\begin{array}{l}\text { Hastalıktan kim } \\
\text { sorumlu? }\end{array}$ & $\begin{array}{l}\text { Bireyde içsel değişiklere neden } \\
\text { olan dişsal faktörler. Hastalık } \\
\text { bireyin kontrolü dışında ortaya } \\
\text { çıan biyolojik değişiklik olduğu } \\
\text { için birey sorumlu tutulamaz. }\end{array}$ & $\begin{array}{l}\text { Bireyler kendi sağlık ve hastalık } \\
\text { durumlarından sorumlu } \\
\text { tutulabilirler. }\end{array}$ \\
\hline $\begin{array}{l}\text { Hastalık nasıl } \\
\text { tedavi edilmeli? }\end{array}$ & $\begin{array}{l}\text { Vücudun fiziksel durumunu } \\
\text { değiştirmeyi amaçlayan, aşılama, } \\
\text { cerrahi ve kemoterapi gibi tıbbi } \\
\text { müdahalelerle. }\end{array}$ & $\begin{array}{l}\text { Davranış değişikliği, hastalığa } \\
\text { olan yaklaşım, tıbbi tedaviye } \\
\text { uyum gibi unsurlarla bireyin } \\
\text { bütüncül olarak tedavi } \\
\text { edilmesi. }\end{array}$ \\
\hline $\begin{array}{l}\text { Tedaviden kim } \\
\text { sorumlu? }\end{array}$ & Hekim & $\begin{array}{l}\text { Amaç sadece fiziksel hastalığın } \\
\text { değil kişinin bütüncül } \\
\text { tedavisi olduğundan davranış } \\
\text { değişikliği ve tedaviye uyum } \\
\text { gibi açılardan hasta da sorumlu } \\
\text { olarak görülmektedir. }\end{array}$ \\
\hline $\begin{array}{l}\text { Sağlık ve hastalık } \\
\text { arasındaki ilişki } \\
\text { nedir? }\end{array}$ & $\begin{array}{l}\text { Sağlık ve hastalık, niteliksel olarak } \\
\text { farklı olgulardır ve ikisi arasında } \\
\text { süreklilik bulunmaz. Kişi sağlıklı } \\
\text { veya hastadır. }\end{array}$ & $\begin{array}{l}\text { Sağlık ve hastalık bir süreklilik } \\
\text { döngüsüne sahiptir. Bireylerin } \\
\text { yaşam döngüsü bu iki durum } \\
\text { arasında ilerler. }\end{array}$ \\
\hline $\begin{array}{l}\text { Zihin ve beden } \\
\text { arasındaki ilişki } \\
\text { nedir? }\end{array}$ & $\begin{array}{l}\text { Zihin ve beden birbirinden } \\
\text { bağımsız çalışır. Zihin ve beden } \\
\text { ayrı varlıklardır. }\end{array}$ & $\begin{array}{l}\text { Odağı, zihin ve beden } \\
\text { arasındaki etkileşimdir. Zihin } \\
\text { ve beden etkileşimde bulunur. }\end{array}$ \\
\hline
\end{tabular}

Kaynak: Simon George Taukeni, "Psychology of Health”, Intecopen 2019. https://www.intechopen.com/books/ psychology-of-health-biopsychosocial-approach, (erişim 16.11.2019).

Biyopsikososyal model birçok açıdan güçlü yönlere sahiptir. Tıbbi müdahale hastanın ihtiyaç ve beklentileri gözetilerek yapılır. Davranış değişikliği yanında psikolojik sağlı̆̆ iyileştirilerek hastanın memnuniyeti artırılır. Hastaneye yeniden yatışları azaltarak maliyetleri düşürür. Kişilerin sağlığını yeniden kazanma sürecinde pasif hasta olmaları yerine aktif katılımcı/paydaş olmaları sağlanır. Hasta ve sağlık profesyonelleri arasındaki iletişimi destekler. Akılcı ilaç kullanımını aktif hale getirir. ${ }^{32}$ Ayrıca biyomedikal modelin sağlık ve hastalık kavramsallaştırması içinde hastanın aktif bir varlık olarak yer alması söz konusu değildir. Kişilerin hastalık 
durumunda adeta tamir edilmesi gereken bir makine olarak ele alındığı ifade edilebilir. Bu yaklaşımın reddiyesi üzerine kurulu sağlık ve hastalığın biyopsikososyal modeli ise kişiyi biyolojik, psikolojik ve sosyal yönleriyle bütüncül bir bakış açısıyla ele almaktadır. Bireyi aktif bir özne olarak tedavi sürecinin aktif bir paydaşı olarak değerlendirmektedir.

Aynı anda varlık gösteren paradigmalar sağlık sisteminin mimarisini değişken hale getirmekte ve farklı uygulama modellerine rastlanabilmektedir. Hastaların sağlık hizmetinin merkezinde yer alması fikri hipokratik tıbbın başlangıcına kadar götürülebilir, ancak hastanın aktif katılımı hususu modern tıbbın uygulandığı on yıllarca sistematik olarak ihmal edilmiştir. Yirminci yüzyıla gelindiğinde, medikal tıp modelinin eleştirisi önem kazanmaya başlamıştır. Öte tandan, en nihayetinde biyomedikal yaklaşımın yararları olduğu ve bunların feda edilmesinin gerekmediğini ve her iki modelin de en iyi sağlı bakımını sağlamak için gerekli olduğu ifade edilebilir. Ayrıca tıp eğitimi uygulamalarında ve diğer sağlık profesyonellerinin eğitiminde dahi sağlık hizmetleri sunumunda biyomedikal modelin devam ettiği belirtilebilir.

Bireyi psikolojik ve sosyal çevresiyle birlikte değerlendiren biyopsikosyal yaklaşımın saha uygulaması sayılabilecek insan odaklı sağlık hizmetinde öncelikle hastaların kendi bireysel bakımlarına katılımları ve daha sonra sağlık profesyonellerinin hasta ile ortak karar verme yönelimi ortaya çıkmıştır. ${ }^{33} \mathrm{Bu}$ nedenle, hasta katılımı gibi uygulamalar sistemin ana karakteristiklerinde değişime yol açmaktadır. Bu tür uygulamaların taşıyıcısı konumundaki sağlık hizmetinin başlıca katalizörleri ise kalite ve akreditasyon çalışmaları olmaktadır. Ayrıca geleneksel olarak, sağlık hizmetleri çalışmalarında maliyet, kalite ve tedaviye erişim sağlık hizmet sunumunun üç ana konusu olarak görülmektedir. Kalite ve akreditasyon çalışmalarının bir bileşeni kabul edilen hasta memnuniyeti ise genellikle tedaviye erişimin özel bir yönü olarak görülür. 30 yılı aşkın bir süredir, sağlık hizmetine erişim, kalite ve memnuniyet sağlık hizmetleri sunumunun önemli yönleri olarak görülmektedir. ${ }^{34}$

\section{İnsan Odaklı Sağlık Hizmetlerinde Kalite ve Akreditasyon}

Son 40 yılda başta sağlık politikalarında trend belirleyici ülkelerin bulunduğu ve sağlık sistemlerini düzenleyici hegemonik kurum ve kuruluşların (Dünya Sağllk Örgütü, Dünya Bankası, Uluslararası Para Fonu, Dünya Ticaret Örgütü, ve OECD gibi) sağlık hizmetlerinin işleyişinde verimlilik, erişilebilirlik, hakkaniyet ve sistem performansını artırmak için oluşturdukları reform programları dünya ve ülke sağlı gündemlerinin ön sıralarında yer almaktadır. 1980 'lerden bu yana görülen ve halen DSÖ verilerine göre yaklaşık 60 ülkede devam eden reform çalışmaları da bu yöndeki arayışların devam ettiğini göstermektedir. Arayışların yönü ise ülkenin ekonomik düzeyi, sağlık sektörünün gelişmişlik düzeyi ve genel sosyo-kültürel ortamından

33 Gamze Bayın, "Sağlık Hizmetlerinin Geliştirilmesi Sürecinde Hasta ve Toplum Katılımının Rolü”, TAF Preventive Medicine Bulletin, 15/5 (2016), s.458-466.

34 Jennie J. Kronenfeld, Access, Quality and Satisfaction With Care: Concerns Of Patients, Providers and Insurers, Amsterdam: Elsevier 2007. 
önemli ölçüde etkilenmektedir.

Bu itibarla, sağlık hizmetleri açısından 1980’lerden sonra dünya ölçeğinde artan reform arayışları ve uygulamaları, küresel reform dalgasının hasta ve sağlık kurumları ve profesyonelleriyle ilişkisini de dönüştürmesi kaçınılmaz olmuştur. Dominic'e göre, sağlık reformlarıyla birlikte sağlık sistemlerinde verimlilik, kalite ve akreditasyon çalışmaları da önemli yer tutmaya başlamıştır. Bu çerçevede, OECD ülkelerinde hükümetlerce sağlık hizmet sunumunu iyileştirmek üzere yerel şartları da gözeten kalite ve akreditasyon programları karşılık bulmuştur. Ayrıca, sosyal ve de kurumsal faydaları önemli görülen bu çalışmalar özel sektör ve de kamu kurumları için de iyi bir yönetim göstergesi olarak kabul görmektedir. ${ }^{35}$ Buna paralel bir şekilde Türkiye Cumhuriyeti Sağlık Bakanlığı tarafından 2003 yılında uygulamaya konan reform programı olan Sağlıkta Dönüşüm Programı ilkeleri arasında başlık olarak kalite ve akreditasyon hususlarına yer verildiğini görmekteyiz. ${ }^{36}$

Sağlık hizmetlerinin odak noktasının değişiminde çekirdek kavram olarak "hasta katılımının” yer aldığını söylemek yanlış olmayacaktır. Sağlık hizmetlerinin ağırlık merkezini kavramsal ve uygulama düzeyinde domine eden çatı yaklaşımlar da yine bu kavram üzerinden ele alınabilir. Dahası sağlık politikacıları ve sağlık hizmetinden yararlanan insanların sağlık hizmetinin sunumundaki rolleri de hâkim modellerin bir yansısı olarak aynı şekilde ele alınmaktadır. Bununla beraber hastaların ve toplumun sağlı̆̆ın iyileştirilmesi ve sağlık politikalarının oluşturulması ve de uygulanması süreçlerine katılımları hızlı bir seyir izlememiştir. 1990’lı yıllarda, özellikle sağlık hizmetinin iyileştirilmesi için kaliteyi geliştirme ve toplam kalite yönetimi gibi çalışmalar dâhilinde hastalar ve toplumun bakış açısına yer verilmesine başlanmıştır. Sağlık hizmetlerine hastanın katılımı, sadece kalite geliştirme çalışmaları nedeniyle değil aynı zamanda diğer sosyal ve politik değişmelerin bir sonucu olarak ortaya çıkmaktadır. ${ }^{37} \mathrm{Bu}$ çerçevede, sağlık reformlarının oluşumu ve uygulanan kararların bireyler ve topluma etkisi ise reform programının nasıl oluşturulduğuna bağlı olmaktadir.

Weiss ve Lynne'ye göre, kamu politikasının en temel ilkesi herhangi bir zamanda, herhangi bir ülkedeki her kamu politikasının benzersiz bir güç yapılandırmasıyla şekillenmekte olduğudur. Kamu politikasının sağlık hizmeti, eğitim veya çevre ilgili olup olmadığı veya hangi ülke olduğu da önemli olmamasına karşın bazı faktörler önemli olduğu ifade edilmektedir. Politik karar alıcıların uygulamalarını etkileyen sayısız sebep ortaya konabilir. Ancak, sağlık hizmetleri ve diğer sosyal sistemler üzerinde, bu güçler arasında oluşan örüntülere göre benzersiz güç yapılandırmasını etkileyen dört ana faktör olduğu belirlenmiştir.

1) Fiziksel çevre (örneğin, çevre kirleticilerinin varlı̆̆ ${ }_{1}$ ve bunlarla mücadele için gerekli maddi kaynaklar)

35 Montagu Dominic, Accreditation and Other External Quality Assessment Systems for Healthcare: Review of Experience and Lessons Learned, Health Systems Resource Centre, 2003.

36 Sağlık Bakanlığı, Sağlıkta Dönüşüm, Ankara: Sağlık Bakanlığı 2003, s.34.

37 Bayın, Sağlık Hizmetlerinin Geliştirilmesi, s.458. 
2) Sağlık politikasını etkileyen tarihsel ve belirli bir olaya özgü durumlar (örneğin, Türkiye’nin 1960 Anayasası ve 2003 yllında Sağlıkta Dönüşüm Reform Programı gibi.)

3) Kültürel normlar ve değerler (örneğin, Türkiyedeki hekimlerin tıbbi pratiklerine hâkim olan değer ve normlar. Hasta ile etkileşimde paternalistik dilin yaygın olması gibi)

4) Toplumun yapısı: siyasi faktörler (merkezi hükümetin rolü ve yapısı), ekonomik faktörler (milli gelir düzeyi), demografik faktörler (nüfus piramidi ve kentlileşme oranı) ve sosyal faktörler (sosyal organizasyonlara ve aileye güven).

Sosyal bilimcilerin tümü bu faktörlere aynı şekilde yaklaşmamaktadır. Çünkü bu faktörlerin her birinin aynı ağırlığa sahip olduğu düşünülmez. Bir kısmı ortaya çıkan sonuçları insanların tercihleri ve oy verme davranışı ile ifade ederken, bir kısmı da "güç grupları" açıklamasını desteklemektedir. Buna göre, sağlık politikaları büyük ölçüde belirli grupların (örneğin özel sağlık sektörü, ilaç firmaları ve sigorta şirketleri gibi) gücü ve etkisi tarafından şekillendirilmektedir. ${ }^{38}$

Biyopsikososyal model, 1980 'lerden sonra yaygın olarak tartışılmaya başlamasına karşın yaklaşımın izlerini taşıyan sağlık politika ve reformları 1990'lı yıllardan sonra başlamıştır. Buna paralel olarak kalite ve akreditasyon çalışmaları da 1990'lardan sonra sağlık kurum ve kuruluşlarının gündeminde yer almaya başlamıştır. ${ }^{39}$ Amerikan Tip Enstitüsünün 2001 yılında yayınladığı "Kalite Uçurumunu Aşmak" isimli raporunda sağlık sisteminin iyileştirilmesi ve geliştirilmesi için belirlediği altı amacının içerisinde sağlık sisteminin hasta odaklı olması gerektiğini belirtmektedir. Bunun aynı zamanda sağlık hizmetinin kalitesi ve hasta güvenliği için esas olduğu ifade edilmiştir. ${ }^{40}$

Herkesçe üzerinde anlaşılmış operasyonel bir tanımı bulunmamasına karşın sağlık hizmetleri açısından kalite kavramının tanımına kısaca yer verecek olursak; Dünya Sağllk Örgütüne göre, "bireylere ve hasta popülasyona verilen sağllk hizmetinin kapsamının arzu edilen sağlık sonuçlarına ulaştırmasıdır. Bunu başarmak içinse sağlık hizmetinin verimli, etkili, adil ve insan merkezli olmalıdır" vurgusuna yer vermektedir. ${ }^{41}$ Sağlık hizmetlerinde kalitenin bir diğer tanımı ise, sunulan hizmetin etkili, güvenli, mükemmellik kültürü ve arzulanan sonuçlar ilkelerini temel alan "mükemmellik kültürünü yansıtan, optimal veya istenen sağllğa ulaşılmasıyla sonuçlanan etkili ve güvenli bakımın değerlendirilmesi ve sağlanması hizmeti" şeklinde ifade edilmiştir. ${ }^{42}$

38 Gregory L. Weiss ve Lynne E. Lonnquist, The Socıology Of Health, Healing and Illness, s.524.

39 Abdullah Alkhenizan ve Charles Shaw, "Impact of Accreditation on the Quality of Healthcare Services: A Systematic Review of the Literature”, Annals of Saudi Medical, 31/4 (2011), s.407-416.

40 Institute of Medicine, Crossing the Quality Chasm: A New Health System for the 21st Century, Washington DC: National Academy Press, 2001.

41 World Health Organization, “How Do We Define Quality of Care”, erişim 15 Kasım 2019, https://www.who.int/ maternal_child_adolescent/topics/quality-of-care/definition/en/.

42 Angela Allen-Duck, Jennifer C. Robinson ve Mary W. Stewart, "Healthcare Quality: A Concept Analysis", Nursing Forum, 52/4 (2017), s.377-386. 
Kalitenin bir yönetim felsefesi olduğu dikkate alınacak olursa uygulama tekniklerinden birisi de akreditasyon çalışmalarıdır. $\mathrm{Bu}$ yönüyle, sağlıkta akreditasyon, bir sağllk kurumunun önceden belirlenmiş standartlara uygunluğunun yerinde değerlendirilmesidir. ${ }^{43-44}$ Tibbi uygulamalardaki farkllıkları azaltmak, uygun olmayan sağlık hizmetini ve artan maliyetleri azaltmak gibi yararları öngören standart seti oluşturmak olarak da görülebilir. Akreditasyon programları, zorunlu ya da gönüllü programlar şeklinde uygulanabilmektedir. Sağlık sisteminin farklı hizmet alanlarından (Hastaneler, birinci basamak sağllk hizmetleri vb.) ortaya çıkan uyaranlara yanıt olarak uygulanagelen karmaşık kalite ve akreditasyon programları esas itibarıla hasta güvenliği müdahaleleridir. Programların başarılı olabilmesi için kamu politikalarıyla sağlık kurumlarının özendirilmesi istendik sonuçların alınması belirleyici olmaktadır. ${ }^{45}$ Kalite ve akreditasyon programlarının sağlık hizmeti sunan kurumlar ve başvuruda bulunan kişiler için başlıca faydaları ifade edilecek olursa: birincisi sağlık hizmet üretim sürecini geliştirmektedir; ikincisi hizmet alan kişilere ait klinik sonuçların iyileştirilmesine katkıda bulunmaktadır; üçüncüsü, sağlık bakım kalitesi ile ilgili olarak hizmet alanların kuruma güvenini artırır; dördüncüsü hizmet alanlar ve çalışanlar açısından zarar görme ve enfeksiyon risklerini azaltmaktır. ${ }^{46}$

Bununla birlikte kalite ve akreditasyon çalışmaları salt belgelendirmeyle eşdeğer tutulmamalıdır. Zira akreditasyon çalışmaları bazı ülkelerde sağlık kuruluşları için mevzuat zorunluluğu olarak ele alınmaktadır. Oysa ki kalite ve akreditasyon faaliyetleri sağlık hizmet süreçlerinin iyileştirilmesi amacıyla uygulama rehberi olarak değerlendirilmelidir.

Hijazi ve ark. (2018) yaptıkları çalışmada, araştırmaya katılan görevli hemşirelerin bakış açısıyla, hasta-kişi merkezli sağlık hizmetleri, gücünü esas olarak kalite çalışmaları alt yapısından ve hastanın amaçlarına değer veren destekleyici politikalarından aldığını belirtmiştir. ${ }^{47}$ Aynı çalışmada, tıbbi açıdan, tedavi ve bakımda kişi merkezli bir yaklaşımın, sağlık kuruluşunun operasyonel işlemlerinde düşünme ve çalışma yöntemlerini değiştirme esasına dayandığı belirtilmiştir. Böylelikle hastaların birer tanı veya semptom olarak değil, planlama, geliştirme ve bakımın değerlendirmesinde eşit katılımına ihtiyaç duyulduğu kişiler haline geldiği ve dolayısıyla hastalar için neyin önemli olduğunu ve hizmet sunumunun kalitesinin nasıl artırılacağını belirlemek için sağlık profesyonellerinin yanında hizmet alan hastalara da karar verme sürecine katılımlarının önemi vurgulanmaktadır. Ayrıca, tedavi ve bakımın hastayı/kişiyi merkeze alan bir şekilde sunulması memnun ve sadık hastalara, gelişmiş bakım uygulamasına ve daha iyi klinik sonuçlara katkı

43 WHO, Quality And Accreditation in Health Care Services: A Global Review, Geneva 2003.

44 Ebrahim Jaafaripooyan, Dila Agrizzi ve Faizollah Akbari-Haghighi, "Healthcare Accreditation Systems: Further Perspectives on Performance Measures", International Journal for Quality in Health Care, 23/6 (2011), s.645-656.

45 Hinchcliff, "Stakeholder perspectives", s. 2.

46 Özden Güdük ve Cenk Hilmi Kılıç, "Sağlık Hizmetleri Akreditasyonu ve Türkiyede Gelişimi”, Düzce Üniversitesi Sağllk Bilimleri Enstitüsü Dergisi, 7/2 (2017), s.102-107.

47 Heba H. Hijazi vd., "The Impact of Applying Quality Management Practices on Patient Centeredness in Jordanian Public Hospitals: Results of Predictive Modeling", The Journal of Health Care Organization, Provision, and Financing, 55(2018), s. 1-15. 
sağlayabileceği ifade edilmiştir. Dolayısıyla, uygulamada hasta ve kişi merkezli sağlık hizmetleri adlandırmasının net bir şekilde ayrıştırılamadığı ama yukarıda yer verilen örneğin ideal tip olarak insan merkezli sağlık hizmeti yaklaşımına dahil olduğu düşünülmektedir.

Günümüzde kalite ve akreditasyon çalışmaları temel olarak hasta güvenliği ve hasta katılımını öne çıkaran bir perspektife sahiptir. Mejdahl ve ark. (2016) yaptıkları çalışmada hasta katılımının bir örneği olarak hastalığına ait sonuçların hastanın kendisi tarafından raporlanmasının kronik böbrek hastalığının anlaşılmasına ve bütünsel olarak hastanın biyolojik ve psikososyal açıdan daha iyi anlaşılmasını sağladığ belirtmiştir. $^{48}$ Hasta deneyimleri ve sağlık hizmetlerinde hasta katılımı, sağlık hizmetinin kalitesi, klinik etkililik ve hasta güvenliğinin temel göstergeleri olarak değerlendirilmektedir.

Andres ve ark. (2019) yaptıkları çalışmada akreditasyon ve dolayısıyla kalite çalışmalarının hasta deneyimlerini iyileştirdiği, hastanın tedavi ve bakım sürecine katılım noktasında algısını $\operatorname{artırdı̆̆}_{1}$ ve hizmeti sunan sağlık profesyonellerinin hastaya duygusal anlamda destek oldukları bulgusuna eriştiklerini vurgulamaktadır. ${ }^{49}$

Wolf ve Boyd (2015) yaptıkları çalışmada insan ve aile odaklı yaklaşımın soyut kavramlar olmadığı ve sağlık hizmet sunum sürecinde (tedavi-bakım) hasta katılımını sağladığı, tedavinin mali yükünü azalttığı ve karar verme tercihlerinde esneklik sağladığı sonucuna ulaştıklarını vurgulamaktadırlar. ${ }^{50}$

İnsan odaklı sağlık hizmetinin, mutlak anlamda sağlık hizmetinin kalitesinin geliştirilmesiyle entegre bir yaklaşım olduğu söylenemez. Ancak, küresel ölçekte hasta katılımını ve hastanın bakış açısının önemini vurgulayan kamu politikalarında

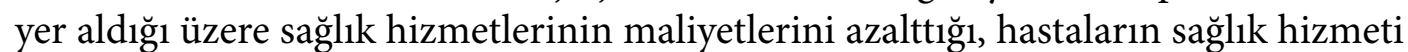
kullanımını makul seviyeye çektiği ve sağlık hizmetinin etkililiğini artırırken hasta deneyimlerini de iyileştirdiği görülmektedir. ${ }^{51} \mathrm{Bu}$ yönüyle insan odaklı yaklaşım, hasta odaklı yaklaşımdan daha çok kalite ve akreditasyon faaliyetlerine uyumlu ve bu faaliyetlerin gelişimine daha uygun olduğu söylenebilir. Çünkü ülke örneklerinde kalite ve akreditasyon faaliyetleriyle birlikte insanların ihtiyaç duyduğu sağlık hizmeti ve sağlı sisteminin etkililiği ve verimliliği artmaktadır. ${ }^{52}$

İnsan odaklı sağlık hizmetine yönelik eleştiriler ise uygulamanın kendisine

48 Caroline Trillingsgaard vd., "Use of Patient-Reported Outcomes in Outpatient Settings as a Means of Patient İnvolvement and Self-Management Support - A Qualitative Study of the Patient Perspective", European Journal for Person Centered Healthcare, 4/2 (2016): s. 359-367.

49 Ellie Bostwick Andres vd., "Can Hospital Accreditation Enhance Patient Experience? Longitudinal Evidence from a Hong Kong Hospital Patient Experience Survey”, BMC Health Services Research, 19/623 (2019): s.2-9. 50 Jennifer L. Wolff ve Cynthia M. Boyd, "A Look at Person-Centered and Family-Centered Care Among Older Adults: Results from a National Survey", Society of General Internal Medicine, 30/10 (2015), s. 497-504.

51 Maria J. Santana vd., "How to Practice Person-Centred Care: A Conceptual Framework", Health Expectations, 21 (2018), s.429-440.

52 Wulan I. R. Sari, "How Does Policy on Accreditation Affect the Quality Improvement in Indonesian Hospitals”, Advances in Economics, Business and Management Research, 35 (2017), s.243-250. 
olmaktadır. Uluslararası Hemşireler Konseyine göre, insan merkezli sağlık hizmeti, gerçekte uygulamada istenen sonuca ulaşamamıştır. Klinisyenler bu fikri destekler gibi görünmesine rağmen mesleki ve kurumsal ihtiyaçlardan dolayı realize edememektedir. Ayrıca, bu modelin gerçekten uygulamasında yaşanan sorunların hastalık sürecine odaklanan tıbbi modelin hâkimiyetinin devam etmesinden kaynaklandığ 1 belirtilmektedir. ${ }^{53}$

Her ne kadar kalite ve akreditasyon faaliyetlerine yaşıt bir geçmişe sahip olmasa da temel felsefi sayıltılarıyla birlikte "insan odaklı sağlık hizmeti” yaklaşımının kalite ve akreditasyon faaliyetlerine sosyo-kültürel açıdan meşru bir zemin oluşturduğu ifade edilebilir.

\section{Sonuç}

Bütün kamu politikalarının arka planında siyasal, ekonomik ve sosyal gerekçeler bulunmaktadır. Keza sağlık politikaları da benzer gerekçeleritaşımaktadır. Öte yandan politikaların uygulama düzeylerinde açık olarak ifade edilmese bile bu gerekçeleri hissetmek her zaman için mümkündür. Sağlık hizmetlerinin merkezi kavramının değişiminde yaşanan süreçler de benzer dinamiklere sahiptir. İnsan odaklı sağlık hizmetleri açısından kalite ve akreditasyon faaliyetleri bu yaklaşımın uygulama aracı olarak görülebilir. Ayrıca, küresel ölçekte insan odaklı bir politika çerçevesi oluşturan Dünya Sağlık Örgütü "insan odaklılığı” sağlık çalışanlarının yetkinliği ve sağlık sisteminin kalitesi için temel önemde bir husus olarak değerlendirmiştir. ${ }^{54}$ $\mathrm{Bu}$ çerçevede, İnsan odaklılık ve sağlık hizmetlerinde kalite ve akreditasyon için şu saptamalar yapılabilir: birincisi insan odaklılık, kalite ve akreditasyon uygulamalarına içkindir. İkincisi kalite ve akreditasyon, sağlı kuruluşları için hastayı bütüncül değerlendirmenin imkânlarını sağlar. Üçüncüsü tarihsel olarak kalite standartlarının belirlenmesi tıp insanlarına delege edilmişken insan odaklı yaklaşım bu sürece hasta katılımını eklemiştir. ${ }^{55}$

$\mathrm{Bu}$ çerçevede, kalite ve akreditasyon uygulamalarının sağlık sistemine entegrasyonunda sistem reformları önemli bir imkân sunmaktadır. Kalite ve akreditasyon çalışmaları birer belgelendirme faaliyeti olarak düşünülmemeli hizmet sunum süreçlerini iyileştirme çabası olarak değerlendirilmelidir. Dikkat edilmesi gereken en önemli hususlar ise, sağlık sisteminin tasarımı ve uygulamalarının gerçekleştirileceği ülkenin sosyo-kültürel bağlamından kopuk olmamasıdır. Ayrıca, sağlık hizmetlerinden arzu edilen sonuçları alabilmenin yollarından birisi de sağlık hizmetleri sunumunun tasarımını insanların duygu, düşünce ve davranışlarını dikkate almak olduğu düşünülmektedir. Bu yönüyle sağlık ve hastalığa yaklaşım sistem tasarımının en önemli belirleyicisi olmaktadır. Ayrıca, sağlık sisteminin önemli bileşeni olan sağlık profesyonellerinin eğitim ve uygulama süreçlerinin bu kavramlar ile irdelenmesine yönelik çalışmalar konuyu zenginleştirecektir.

53 Uluslararası Hemşireler Konseyi, ICN 2018 Tema Özeti, 2018, s.14. (erişim 20.12.2019)

54 World Health Organization, People-Centred Health Care: A Policy Framework, Geneva: WHO, 2007.

55 Syed Saad Andaleeb, "Service Quality Perceptions and Patient Satisfaction: A Study of Hospitals in a

Developing Country”, Social Science \& Medicine, 52 (2001), s. 1359-1370. 


\section{Kaynakça}

Alkhenizan, Abdullah and Charles Shaw. "Impact of Accreditation on the Quality of Healthcare Services: A Systematic Review of the Literature". Annals of Saudi Medical. 31/4 (2011): 407-416.

Alvarez, Ana Sabela, Marco Pagani and Paolo Meucci. "The Clinical Application of the Biopsychosocial Model in Mental Health: A Research Critique". American Journal of Physical Medicine \& Rehabilitation. 91(2012): 173-180.

Andaleeb, Syed Saad. "Service Quality Perceptions and Patient Satisfaction: A Study of Hospitals in a Developing Country". Social Science \& Medicine. 52 (2001): 1359-1370.

Anjum, Rani Lill, Samantha Copeland, Stephen Mumford and Elena Rocca. "Integrating Philosophical Perspectives into Person Centered Healthcare". European Journal for Person Centered Healthcare. 3/4 (2015): 427-430.

Aytaç, Ömer ve Muzaffer Çağlar Kurtdaş. "Sağlık - Hastalığın Toplumsal Kökenleri ve Sağlık Sosyolojisi”. Fırat Üniversitesi Sosyal Bilimler Dergisi. 25/1 (2015): 231250.

Bayın, Gamze. "Sağlık Hizmetlerinin Geliştirilmesi Sürecinde Hasta ve Toplum Katılımının Rolü”. TAF Preventive Medicine Bulletin. 15/5 (2016): 458-466.

Dogar, Ahmad Imtiaz. “Biopsychosocial Model”. Annals of Punjab Medical College. 1/1 (2007): 11-13.

Dominic, Montagu. "Accreditation and Other External Quality Assessment Systems for Healthcare: Review of Experience and Lessons Learned". Health Systems Resource Centre, 2003.

Duck, Angela Allen, Jennifer C Robinson and Mary W Stewart. "Healthcare Quality: A Concept Analysis". Nursing Forum. 52/4 (2017): 377-386.

Edwards, Gemma. "Jürgen Habermas Politics and Morality in Health and Medicine". Contemporary Theorists for Medical Sociology. Ed., Graham Scambler. New York Rotledge, 2012.

Ellie Bostwick Andres, Wen Song, Wei Song and Janice Mary Johnston. "Can Hospital Accreditation Enhance Patient Experience? Longitudinal Evidence from a Hong Kong Hospital Patient Experience Survey". BMC Health Services Research. 19/623 (2019): 2-9.

Engel, George. L. “The Need for a New Medical Model: A Challenge for Biomedicine”. Science. 196 (1977): 129 - 136.

Erbaydar, Tuğrul. “Sağlık; Kimin için?”. Toplumbilim Dergisi. 13 (2001):49-58.

Fix, Gemmae M, Carol Van Deusen, Lukas Ed, Rendelle E. Bolton, Jennifer N. Hill, Nora Mueller, Sherri L. LaVela and Barbara G. Bokhour. "Patient-Centred Care is a Way of Doing Things: How Healthcare Employees Conceptualize Patient-Centred Care". Health Expectations. 21/1 (2018): 300-307.

Alexander R. Green, Juan Emilio Carrillo ve Joseph R. Betancourt. "Why The DiseaseBased Model of Medicine Fails Our Patients". Western Journal of Medicine. 176/2 (2002):141-143. 
Güdük, Özden ve Cenk Hilmi Kılıç. “Sağlık Hizmetleri Akreditasyonu ve Türkiye’de Gelişimi”. Düzce Üniversitesi Sağlık Bilimleri Enstitüsü Dergisi. 7/2 (2017): 102107.

Havelka, Mladen, Despot Jasminka Lucanin ve Damir Lucanin. "Biopsychosocial Model - The Integrated Approach to Health and Disease". Collegium Antropologium. 33/1 (2009): 303-310.

Hijazi Heba H., Harvey Heather L., Alyahya Mohammad S., Alshraideh Hussam A., Al Abdi Rabah M. ve Parahoo Sanjai K. “The Impact of Applying Quality Management Practices on Patient Centeredness in Jordanian Public Hospitals: Results of Predictive Modeling". The Journal of Health Care Organization, Provision, and Financing. 55 (2018): 1-15.

Hinchcliff, Reece, David Greenfield, Johanna I. Westbrook, Marjorie Pawsey, Virginia Mumford ve Jeffrey Braithwaite. "Stakeholder Perspectives on İmplementing Accreditation Programs: A Qualitative Study of Enabling Factors". BMC Health Services Research. 13 (2013): 2-9.

Institute of Medicine. Committee on Quality of Health Care in America. Crossing the Quality Chasm: A New Health System for the 21st Century. Washington DC: National Academy Press; 2001.

Jaafaripooyan, Ebrahim, Dila Agrizzi, Faizollah Akbari-Haghighi, "Healthcare Accreditation Systems: Further Perspectives On Performance Measures". International Journal for Quality in Health Care. 23/6 (2011): 645-656.

Jennifer L. Wolff and Cynthia M. Boyd. "A Look at Person-Centered and FamilyCentered Care Among Older Adults: Results from a National Survey". Society of General Internal Medicine. 30/10 (2015): 1497-504.

Kasapoğlu, Aytül. "Güncel Sosyal Sorunlar ve Sağlık”. Toplumbilim, Sağlık Sosyolojisi Özel Sayısı. 13 (2001): 23-37.

Kronenfeld, Jennie ve J. Access, Quality and Satisfaction With Care: Concerns of Patients, Providers and Insurers. Amsterdam, Elsevier 2007.

Kuhn, Thomas. The Structure of Scientific Revolutions. London: The University of Chicago Press, 1996.

Kumbasar, Banu. "Hasta Odaklı Sağlık Hizmetlerinde İletişim”. Sağlık Bilimleri ve Meslekleri Dergisi. 3/1 (2016): 85-90.

Lidia Borghi, Federica Galli, Maria, Vegni Elena Anna. "Promoting Patient Engagement and Participation for Effective Healthcare Reform". Ed., Guendalina Graffigna, The Patient-Centered Medicine as the Theoretical Framework for Patient Engagement. USA: IGI Global, 2016.

Maeseneer Jan De, Chris Van Weel, Lieve Daeren, Christine Leyns, Peter Decat, Pauline Boeckxstaens, D. Avonts ve Sara Willems. "From "Patient" To "Person" To "People": The Need For İntegrated, People-Centered Healthcare". The International Journal of Person Centered Medicine. 2/3 (2012): 601-614.

May, Carl. "Mundane Medicine, Therapeutic Relationships, and the Clinical Encounter: Current and Future Agendas for Sociology". Handbook of the Sociology of Health, Illness and Healing. Ed., Bernice A. Pescosolido, Jack K. 
Martin, Jane D. McLeod, Anne Rogers. London: Springer, 2011.

Mejdahl Caroline Trillingsgaard, Nielsen Berit Kjærside, Hjøllund Niels Henrik ve Lomborg Kirsten."Use of Patient-Reported Outcomes in Outpatient Settings as a Means of Patient İnvolvement and Self-Management Support - a Qualitative Study of the Patient Perspective". European Journal for Person Centered Healthcare. 4/2 (2016): 359-367.

Miles, Andrew ve Juan E. Mezzich. "The Care of the Patient and the Soul of the Clinic: Personcentered Medicine as an Emergent Model of Modern Clinical Practice". The International Journal of Person Centered Medicine. 1/2 (2011): 207-222.

Morton, Rachael L. ve Marcus Sellars, "From Patient-Centered to Person-Centered Care for Kidney Diseases". Clinical Journal of the American Society of Nephrology. 14 (2019) : 623-625.

Netletton, Sarah. The Sociology of Health and Ilness. Cambridge: Polity Press, 1995.

Quintana, Yuri, Nancy M. Lorenzi ve Mordechai Shani. "People Centered Healthcare Systems: Opportunities and Challenges”. British Medical Journal Satellites. 18 (2011): 17-24.

Reynolds, April. “Patient-Centered Care”. Radiol Technol. 81 (2009):133-147.

Sağlık Bakanlığı. Sağlıkta Dönüşüm. Ankara: Sağlık Bakanlığı, 2003.

Santana, Maria J., Kimberly Manalili, Rachel J. Jolley, Sandra Zelinsky, Hude Quan ve Lu Mingshan. "How to Practice Person-Centred Care: A Conceptual Framework". Health Expectations. 21 (2018): 429-440.

Sari, Wulan I. R. "How Does Policy on Accreditation Affect the Quality Improvement in Indonesian Hospitals". Advances in Economics, Business and Management Research. 35 (2017): 243-250.

Şahin, Gülay ve Füsun A. İğde Artıran. "Hasta Merkezli Bakım-Ortak Karar Alma Süreci ve Kalite". Türkiye Klinikleri Journal Of Family Medicine-Special Topics. 5/3 (2014): 38-42.

Taukeni, Simon George. "Psychology of Health". Intecopen. 2019. https://www. intechopen.com/books/psychology-of-health-biopsychosocial-approach (erişim, 16.11.2019)

The American Geriatrics Society. "Person-Centered Care: A Definition and Essential Elements". Journal of American Geriatrics Society. 64 (2016): 15-18.

Thomas, Richard K. Society and Health-Sociology for Health Professionals. New York: Kluwer Academic Publishers, 2003.

Uluslararası Hemşireler Konseyi. "ICN 2018 Tema Özeti”. 2018. https://medicana. com.tr/Assets/uploads/icn-2018-45867.pdf (erişim 20.12.2019)

Weiss, Gregory L. ve Lynne E. Lonnquist. The Sociology of Health, Healing, and Illness. New York: Routledge, 2016.

World Health Organization. People Centered Healthcare. Geneva, 2008. https://iris. wpro.who.int/bitstream/handle/10665.1/5453/9789290613930_eng.pdf (erişim, 10.10.2019)

World Health Organization. Quality AndAccreditation in Health CareServices: A Global 
Review. Geneva: WHO, 2003. https://apps.who.int/iris/handle/10665/68410 (erişim, 11.10.2019)

World Health Organization. "How Do We Define Quality of Care". (Son güncelleme 15 Kasım 2019), https:/www.who.int/maternal_child_adolescent/topics/ quality-of-care/definition/en/

WorldHealthOrganization.People-CenteredCareinLow-andMiddle-İncomeCountries. World Health Organization 2010. https://www.personcenteredmedicine.org/ doc/genevathree/geneva2011i.pdf (erişim, 10.10.2019)

World Health Organization. People-Centred Health Care: A Policy Framework. Geneva: WHO, 2007. https://iris.wpro.who.int/handle/10665.1/5420 (erişim, $11.10 .2019)$ 


\title{
Health Conceptualization and Quality and Accreditation Perspective in Person-Centered Health Care
}

BAYRAM DEMİR

\begin{abstract}
In the historical process, the focus object of health services has changed in different societies and times. These concepts, which are centered on healthcare services such as diseasecentered care, patient-centered care, community-centered care and person-centered care, have been determinative in the design of health care system. The biomedical model and biopsychosocial model are the most important conceptual approaches that provide a framework for these types of care. These models, which determine the perceptions of disease and health status, have different assumptions about human and human health status. Until the 1980s, there was a field of health services and medical practices dominated by the biomedical model. The introduction of a different perspective on the definition of health by WHO in 1948 enabled the development of the biopsychosocial model. The health reform wave that began in the 1980s, and in the 1990s, quality and accreditation activities that are compatible with human-centered health care were integrated into health systems. In this study, the relationship between biopsychosocial model and person-centered health practices and quality accreditation studies is discussed.
\end{abstract}

Keywords: Person-Centered health service, Biomedical model, Biopsychosocial model, Quality, Accreditation. 